\title{
Cadmium Concentration in Brown and Polished Rice from Selected Farms in Barangay Real, Calamba City and its Potential Non-cancer Health Risk in Adult Population
}

\author{
Cyreene S. Fontanilla, ${ }^{1}$ Romeo R. Quizon, ${ }^{1}$ Victorio B. Molina, ${ }^{1}$ Vivien Fe F. Fadrilan-Camacho, \\ Maylin C. Palatino ${ }^{2}$ and Virginia C. Cuevas ${ }^{3}$ \\ ${ }^{1}$ Department of Environmental and Occupational Health, College of Public Health, University of the Philippines Manila \\ ${ }^{2}$ Department of Epidemiology and Biostatistics, College of Public Health, University of the Philippines Manila \\ ${ }^{3}$ Institute of Biological Sciences, College of Arts and Sciences, University of the Philippines Los Baños
}

\begin{abstract}
Objectives. This study was conducted to determine the cadmium (Cd) concentration in brown and polished rice collected from the 9 farms in Barangay Real, Calamba City. This study also assessed the non-cancer health risk to adults ( $\geq 20$ years old) of long-term consumption of rice with $\mathrm{Cd}$ using the non-cancer hazard quotient (NHQ).

Methods. Rice grains with hull were collected in NovemberDecember 2013. Both rice types were analyzed for Cd using a graphite furnace atomic absorption spectrophotometer (GFAAS). The $\mathrm{NHQ}$ was calculated by dividing the estimated daily intake of $\mathrm{Cd}$ via rice consumption by the oral reference dose (RfD) for $\mathrm{Cd}$.

Results. Mean $\mathrm{Cd}$ concentrations in brown and polished rice collected from the 9 farms in Barangay Real ranged from 0.0062 to $0.0725 \mathrm{mg} / \mathrm{kg}$ and 0.0047 to $0.0778 \mathrm{mg} / \mathrm{kg}$, respectively. The $\mathrm{NHQ}$ values of $\mathrm{Cd}$ in both rice types were less than 1.0 for adults ( $\geq 20$ years old).
\end{abstract}

Conclusion. $\mathrm{Cd}$ concentrations in brown and polished rice from the 9 farms did not exceed the $0.4 \mathrm{mg} / \mathrm{kg}$ maximum allowable $\mathrm{Cd}$ concentration in rice set by FAO/WHO. Since the NHQ did not exceed 1.0, long-term exposure to $\mathrm{Cd}$ through consumption of brown and polished rice from these farms is unlikely to cause non-cancer health effects in adults ( $\geq 20$ years old). It is unlikely for adults to develop kidney diseases such as tubular proteinuria, decreased glomerular filtration rates, and itai-itai disease.

Key Words: Cadmium, brown rice, polished rice, non-cancer hazard quotient

\section{Introduction}

Cadmium (Cd) is a toxic and persistent metal in the environment. It has no function in any known biological organism. ${ }^{1}$ It is therefore not essential for the growth and development of plants, animals, and humans. Industrial emission, mining and refining of metals, and application of Cd-rich phosphatic fertilizers, farmyard manure, sewage sludges and municipal composts deposit considerable amounts of $\mathrm{Cd}$ on agricultural soil. ${ }^{2} \mathrm{Cd}$ is used as protective plating on steel, stabilizers for polyvinylchloride, pigments in plastics and glass, electrode material in nickel-Cd batteries, and component of various alloys. ${ }^{3} \mathrm{Cd}$ accumulates in the soil with an estimated half-life varying between 15 and 1,100 years. ${ }^{4}$ Food crops that absorb and accumulate $\mathrm{Cd}$ in their edible portions pose a health risk to humans.

The kidney is the critical target organ of $\mathrm{Cd}$ and is the first organ to display signs of toxicity. ${ }^{5}$ The accumulation of $\mathrm{Cd}$ in the proximal tubules of the kidney leads to tubular dysfunction. ${ }^{6}$ Tubular dysfunction is manifested as tubular proteinuria, usually detected as increased urinary excretion of low molecular weight proteins. Among these proteins, $\beta_{2}-$ microglobulin, $N$-acetyl- $\beta$-D-glucosaminidase (NAG), and $\alpha_{1}$-microglobulin (protein $\mathrm{HC}$ ) are the common urinary markers of tubular proteinuria. Continued exposure to $\mathrm{Cd}$ may cause tubular dysfunction to progress to glomerular damage with decreased glomerular filtration rates (GFRs). ${ }^{7}$ The most severe form of chronic $\mathrm{Cd}$ intoxication is itai-itai disease, which is characterized by severely impaired tubular and glomerular function and generalized osteomalacia and osteoporosis. ${ }^{8,9}$ These are some of the non-cancer health risks of oral exposure to $\mathrm{Cd}$.

Rice is a staple food in Asian countries such as Japan and China. Unfortunately, it is also a significant source of $\mathrm{Cd}$. In Toyama Prefecture, Japan, the elevated level of Cd in rice was a causative factor in the occurrence of itai-itai disease in the 1960s. ${ }^{1}$ Elevated levels of $\mathrm{Cd}$ were also detected in some samples of brown and polished rice from Guangdong and Taizhou, China. In Guangdong, Yang et al. revealed in their study in 2006 that $0.03-0.46 \mathrm{mg} / \mathrm{kg}$ Cd was detected in brown rice from rice plants growing near 
Lechang lead/zinc mine. ${ }^{10}$ In Taizhou, Fu et al. reported in 2008 that polished rice collected from contaminated rice paddies near e-waste recycling areas contained 0.012-0.66 $\mathrm{mg} / \mathrm{kg} \mathrm{Cd}$. Both studies revealed that $\mathrm{Cd}$ concentrations in some brown and polished rice samples exceeded the 0.2 $\mathrm{mg} / \mathrm{kg}$ safety limit for $\mathrm{Cd}$ in rice in China. ${ }^{11}$ However, the maximum allowable concentration of $\mathrm{Cd}$ in rice set by $\mathrm{FAO} / \mathrm{WHO}$ is higher at $0.4 \mathrm{mg} / \mathrm{kg} \cdot{ }^{12}$

There is limited information on the Cd content of rice locally grown in the Philippines. About 18.72 hectares of lowland irrigated rice fields can be found in Barangay Real, an urban barangay in Calamba City. ${ }^{13}$ This city has 7,662 establishments and 12 industrial parks, with plastic, electronic parts, semiconductors, and automotive parts as their major industrial products. ${ }^{14}$ These products may contain $\mathrm{Cd}$ because the element is used as pigment for plastics and in metal plating. ${ }^{3}$ The industries involved in the production and use of $\mathrm{Cd}$ can release considerable amounts of this metal into agricultural soils and receiving waters such as irrigation water, creeks, and rivers. Rice plants absorb and accumulate $\mathrm{Cd}$ in the grains. The presence of elevated levels of $\mathrm{Cd}$ in grains is an indicator of $\mathrm{Cd}$ pollution in the environment.

This study aimed to determine the Cd concentration in brown and polished rice from the 9 farms in Barangay Real, Calamba City. The risk of non-cancer health effects to adults ( $\geq 20$ years old) from long-term consumption of rice with $\mathrm{Cd}$ using the non-cancer hazard quotient (NHQ) was also assessed.

\section{Materials and Methods}

\section{Study Setting}

There are 12 farms in Barangay Real, Calamba City with a total land area of 18.72 ha. Only 9 farms, with a total land area of $11.92 \mathrm{ha}$, were covered in this study. The remaining 3 farms were not sampled because the rice plants were not ready for harvest until the last week of March 2014 and stored rice grains were not available during the sampling period (November-December 2013).

\section{Sampling}

Rice plants grown in farms 1, 4, 5, 6, 7, 8, and 9 were harvested from the last week of November to the first week of December 2013. Rice plants were randomly collected starting from the four corners and then towards the center of each farm. Rice grains were then detached from the panicles and mixed together as one composite sample. At least $1 \mathrm{~kg}$ of composite rice grains with hull was collected from each farm. For farms 2 and 3, grains that were stored after harvest in the third week of October 2013 were collected from storage bins in the last week of November 2013. The farmers stated the varieties of rice they planted in their farms.

\section{Dehulling or Milling of Rice Grains}

Nine labelled bags of air-dried rice grains with hull were brought to the Analytical Services Laboratory of the International Rice Research Institute (IRRI) for dehulling and milling. The rice grains with hull turned into brown rice after passing through a Satake husker. The brown rice was further milled using a Grainman mill, which produces polished rice after the bran layers are removed.

\section{Digestion of Sample and Analysis of Cd}

Weighed $(0.5 \pm 0.05 \mathrm{~g})$ test portions of ground rice grain were placed in $10 \mathrm{~mL}$ of concentrated nitric acid $\left(\mathrm{HNO}_{3}\right)$ contained in an open tube $(2.5 \times 20 \mathrm{~cm}$ digestion tubes $)$ and pre-digested overnight at ambient temperature $\left(22-26^{\circ} \mathrm{C}\right)$. After pre-digestion, the samples were transferred to a temperature-controlled block digestor for 6 hours at $125^{\circ} \mathrm{C}$ and diluted to the $25 \mathrm{~mL}$ calibration mark with $1 \%$ nitric acid. Analysis of the Cd content of the digest was done in duplicate using GFAAS (Perkin Elmer HGA 900 Graphite Furnace, with AS 800 Autosampler and AAnalyst 400 atomic absorption spectrometer equipped with $\mathrm{Cd}$ electrodeless discharge lamp). For graphite furnace operation, gaseous argon was used. Absorption of the solution was measured at $228.8 \mathrm{~nm}$. Limit of detection of Cd was at $0.0017 \mathrm{mg} / \mathrm{kg}$.

About 24 paired samples of brown and polished rice were analyzed for $\mathrm{Cd}$. These samples were divided among the 9 farms depending on the size of the farm (Table 1).

Table 1. Number of paired brown and polished rice samples allotted for each farm for $\mathrm{Cd}$ analysis.

\begin{tabular}{ccc}
\hline Farm & Size (ha) & No. of Paired Rice Samples \\
\hline 1 & 3.42 & 4 \\
2 & 1.25 & 3 \\
3 & 0.75 & 2 \\
4 & 0.6 & 2 \\
5 & 1.9 & 3 \\
6 & 1.0 & 3 \\
7 & 0.5 & 2 \\
8 & 2.0 & 3 \\
9 & 0.5 & 2 \\
TOTAL & 11.92 & 24 \\
\hline
\end{tabular}

\section{Quality Control}

The instrument settings were optimized and checked if the required sensitivity was achieved through the results of sensitivity check standard. Instrument calibration using the working standards was performed. The overall performance in each step of the analysis was also monitored by the use of suitable reference materials (RMs). Internal and external RMs traceable to National Institute of Standards and Technology (NIST) or National Institute for Environmental Studies (NIES) standards were incorporated for every batch of samples analyzed. 


\section{Non-cancer Risk Characterization of Cd through Rice} Consumption

\section{Estimated Daily Intake (EDI)}

The estimated daily intake (EDI) of Cd depends on the concentration of $\mathrm{Cd}$ in brown and polished rice and the associated amount of rice consumption. ${ }^{15}$ The EDI was determined using the following equation:

$$
\begin{aligned}
\text { EDI }= & \frac{\mathrm{C} \times \text { Con } \times \text { EF } \times \text { ED }}{\text { Bw } \times \text { AT }} \\
\mathrm{C}= & \text { mean Cd concentration in rice }(\mathrm{mg} / \mathrm{kg}) \\
\mathrm{Con}= & \text { average daily consumption of rice by Filipinos } \\
= & \text { brown rice: } 230.14 \mathrm{~g} / \text { person }^{16} \\
= & \text { polished rice: } 326.25 \mathrm{~g} / \text { person }^{17} \\
\mathrm{EF}= & \text { exposure frequency }(365 \text { days } / \text { year }) \\
\mathrm{ED}= & \text { exposure duration }(30 \text { years }) \\
\mathrm{BW}= & \text { average adult body weight }(\geq 20 \text { years old for } \\
& \text { both gender }) \\
= & 54.77 \mathrm{~kg} / \text { person }{ }^{18} \\
\mathrm{AT}= & \text { averaging time }=\mathrm{ED} \times 365 \text { day } / \text { year }=10,950 \\
& \text { days }
\end{aligned}
$$

The exposure frequency is set at 365 days/year since Filipinos consume rice daily. For non-cancer health effects, 30 years is used as the default exposure duration that is the $90^{\text {th }}$ percentile for time spent at one residence. ${ }^{15}$

The average body weight $(54.77 \mathrm{~kg}$ ) was computed as an average of adult mean body weights for both males and females, aged 20-39, 40-59, 60 years and above at $56.44 \mathrm{~kg}$, $57.28 \mathrm{~kg}$, and $50.6 \mathrm{~kg}$, respectively. ${ }^{18}$ Average daily consumption of polished rice by Filipinos is $326.25 \mathrm{~g} /$ person, which is calculated from the $119.08 \mathrm{~kg}$ average annual per capita consumption of rice. ${ }^{17}$ Mendoza, a crop scientist at the University of the Philippines Los Baños, has said that with brown rice Filipinos will only consume an average of $84 \mathrm{~kg}$ per capita per year or $230.14 \mathrm{~g}$ daily consumption per person. ${ }^{16}$

Non-cancer Hazard Quotient (NHQ)

$$
\begin{aligned}
& \mathrm{NHQ}=\frac{\mathrm{EDI}}{\mathrm{RfD}} \\
& \mathrm{EDI}=\text { Estimated Daily Intake } \\
& \mathrm{RfD}=\text { Reference Dose for } \mathrm{Cd}=0.001 \mathrm{mg} / \mathrm{kg} / \text { day }^{19}
\end{aligned}
$$

The possibility of non-cancer health effects from longterm consumption of brown and polished rice with $\mathrm{Cd}$ to adults ( $\geq 20$ years old) was evaluated using the NHQ. This compares an exposure level (EDI) over a specified time period with a reference dose (RfD) derived for a similar exposure period. If NHQ is less than or equal to 1.0, it is unlikely for even sensitive populations to experience non- cancer health effects. If it exceeds 1.0, there may be concern for potential non-cancer health effects. ${ }^{20}$

NHQ assumes that there is a level of exposure (i.e., RfD) below which it is unlikely for even sensitive populations to experience adverse health effects. ${ }^{20}$ Specifically, the RfD for $\mathrm{Cd}$ is based on the highest level of $\mathrm{Cd}$ in the human renal cortex (i.e., the critical level) not associated with significant proteinuria (i.e., the critical effect). ${ }^{19}$ Tubular proteinuria is the earliest manifestation of Cd-induced renal damage, particularly to the proximal tubules where $\mathrm{Cd}$ mainly accumulates. $^{5}$

\section{Results}

\section{Cd Concentration in Rice in the Nine Farms}

In all the 9 farms in Barangay Real, the mean $\mathrm{Cd}$

\begin{tabular}{|c|c|c|c|c|}
\hline \multirow[t]{2}{*}{ Farm } & \multirow{2}{*}{$\begin{array}{c}\text { No. of } \\
\text { samples }\end{array}$} & \multirow{2}{*}{ Variety } & \multicolumn{2}{|c|}{$\begin{array}{c}\text { Mean Cd Concentration } \\
(\mathrm{mg} / \mathrm{kg})\end{array}$} \\
\hline & & & Brown Rice & Polished Rice \\
\hline 1 & 4 & $\begin{array}{c}\text { NSIC Rc } 238 \\
\text { with } 2 \% \text { red rice }\end{array}$ & 0.0725 & 0.0778 \\
\hline 2 & 3 & NSIC Rc 238 & 0.0062 & 0.0047 \\
\hline 3 & 2 & NSIC Rc 148 & 0.0195 & 0.0195 \\
\hline 4 & 2 & $\begin{array}{c}\text { NSIC Rc } 238 \\
\text { with }<1 \% \text { red rice }\end{array}$ & 0.0165 & 0.0135 \\
\hline 5 & 3 & NSIC Rc 148 & 0.0190 & 0.0167 \\
\hline 6 & 3 & NSIC Rc 238 & 0.0240 & 0.0207 \\
\hline 7 & 2 & $\begin{array}{c}\text { NSIC Rc } 238 \\
\text { with } 10 \% \text { red rice }\end{array}$ & 0.0395 & 0.0385 \\
\hline 8 & 3 & $\begin{array}{l}\text { NSIC Rc } 128 \\
\text { with } 5 \% \text { red rice }\end{array}$ & 0.0237 & 0.0217 \\
\hline 9 & 2 & $\begin{array}{c}\text { NSIC Rc } 238 \\
\text { with }<1 \% \text { red rice }\end{array}$ & 0.0320 & 0.0315 \\
\hline $\begin{array}{l}\text { TOTAL } \\
\text { (all farms) }\end{array}$ & 24 & - & 0.0302 & 0.0295 \\
\hline
\end{tabular}
concentration in brown rice was $0.0302 \mathrm{mg} / \mathrm{kg}$, which ranged from 0.0062 to $0.0725 \mathrm{mg} / \mathrm{kg}$. In polished rice, the mean $\mathrm{Cd}$ concentration in all the 9 farms was $0.0295 \mathrm{mg} / \mathrm{kg}$, ranging from 0.0047 to $0.0778 \mathrm{mg} / \mathrm{kg}$ (Table 2).

The mean $\mathrm{Cd}$ concentrations in both brown $(0.0725$ $\mathrm{mg} / \mathrm{kg})$ and polished rice $(0.0778 \mathrm{mg} / \mathrm{kg})$ collected from farm 1 were the highest among the 9 farms. This was followed by farm 7 with $0.0395 \mathrm{mg} / \mathrm{kg} \mathrm{Cd}$ in brown rice and 0.0385 $\mathrm{mg} / \mathrm{kg} \mathrm{Cd}$ in polished rice. The lowest mean $\mathrm{Cd}$ concentrations in both brown $(0.0062 \mathrm{mg} / \mathrm{kg})$ and polished rice $(0.0047 \mathrm{mg} / \mathrm{kg})$ was collected in farm 2 .

Table 2. Mean $\mathrm{Cd}$ concentration $(\mathrm{mg} / \mathrm{kg})$ in brown and polished rice collected from the 9 farms in Barangay Real, Calamba City.

NHQ Values for Adults ( $\geq 20$ years old) in Rice in the Nine Farms

In all the 9 farms, the calculated NHQ value for adults for brown rice was 0.1269 while that for polished rice was 0.1757 . The NHQ values in both rice types in the 9 farms did not exceed 1.0 (Table 3 ). 
Table 3. Summary of the NHQ values for adults ( $\geq 20$ years old) in the 9 farms in Barangay Real, Calamba City.

\begin{tabular}{ccc}
\hline \multirow{2}{*}{ Farm } & \multicolumn{2}{c}{ NHQ } \\
\cline { 2 - 3 } & Brown Rice & Polished Rice \\
\hline 1 & 0.3046 & 0.4634 \\
2 & 0.0261 & 0.0280 \\
3 & 0.0819 & 0.1162 \\
4 & 0.0693 & 0.0804 \\
5 & 0.0798 & 0.0995 \\
6 & 0.1008 & 0.1233 \\
7 & 0.1660 & 0.2293 \\
8 & 0.0994 & 0.1293 \\
9 & 0.1345 & 0.1876 \\
TOTAL (all farms) & 0.1269 & 0.1757 \\
\hline
\end{tabular}

\section{Discussion}

\section{Cd Concentration in Rice in the Nine Farms}

In the 9 farms in Barangay Real, Calamba City, the mean $\mathrm{Cd}$ concentration reached up to $0.0725 \mathrm{mg} / \mathrm{kg}$ in brown rice while $0.0778 \mathrm{mg} / \mathrm{kg}$ in polished rice (Table 2). These levels did not exceed the maximum allowable $\mathrm{Cd}$ concentration in rice set by $\mathrm{FAO} / \mathrm{WHO}$, which is $0.4 \mathrm{mg} / \mathrm{kg} .{ }^{12}$

In another study conducted in Naboc area, Mindanao, Philippines, the $\mathrm{Cd}$ content of rice reached as high as 1.025 $\mathrm{mg} / \mathrm{kg}$. This exceeded the $0.4 \mathrm{mg} / \mathrm{kg} \mathrm{Cd}$ limit in rice. Naboc area is near a gold mine with paddy soil containing less than $1 \mathrm{mg} / \mathrm{kg} \mathrm{Cd}$. Specifically, the Cd content of rice from this area ranged from 0.057 to $1.025 \mathrm{mg} / \mathrm{kg}$, with a mean of $0.2907 \mathrm{mg} / \mathrm{kg} .{ }^{21}$

On the other hand, Solidum et al. studied the $\mathrm{Cd}$ content of the 10 types/varieties of rice (cooked), sold in a market in Manila. The source of the rice, whether the rice was imported or locally grown, was unknown. The study revealed that $\mathrm{Cd}$ concentrations in the 10 types/varieties of cooked rice did not exceed the maximum allowable $\mathrm{Cd}$ concentration in rice. About $0.0127-0.0143 \mathrm{mg} / \mathrm{kg} \mathrm{Cd}$ was detected from cooked whole grain, sinandomeng, violet malagkit, passion, brown rice, jasmine, malagkit, dinurado, red rice, and National Food Authority (NFA) rice.22

\section{Non-cancer Risk Characterization of Cd in Rice}

$\mathrm{Cd}$ accumulates mainly in the proximal tubules of the kidneys with a biological half-life of about $10-30$ years. It is very poorly excreted through urine and feces, with only about $0.001 \%$ of the body burden excreted per day. ${ }^{23}$ The non-cancer health effects of $\mathrm{Cd}$ through oral intake include tubular proteinuria, decreased glomerular filtration rates, and itai-itai disease (kidney failure and bone disease). ${ }^{7-9}$

The possibility of non-cancer health effects from longterm consumption of brown and polished rice with $\mathrm{Cd}$ to adults ( $\geq 20$ years old) was evaluated using the NHQ. In all the 9 farms, the NHQ values of $\mathrm{Cd}$ in both brown and polished rice were less than 1.0 for adults (Table 3 ). This means that it is unlikely for adults ( $\geq 20$ years old) to experience non-cancer health effects as a result of long-term consumption of brown or polished rice with low Cd content from Barangay Real.

However, it should be noted that this study only considered the intake of $\mathrm{Cd}$ via rice consumption. There are also other possible food sources of $\mathrm{Cd}$ such as vegetables, shellfish and crustaceans as well as drinking water. ${ }^{24}$ Inhalation and dermal absorption are other routes of $\mathrm{Cd}$ exposure. ${ }^{25}$ Thus, there are other sources of $\mathrm{Cd}$ that can contribute to the total Cd burden of the human body.

\section{Conclusion and Recommendations}

Brown rice from all the 9 farms in Barangay Real included in the study had a mean Cd concentration of 0.0302 $\mathrm{mg} / \mathrm{kg}$, ranging from 0.0062 to $0.0725 \mathrm{mg} / \mathrm{kg}$ while polished rice had a mean Cd concentration of $0.0295 \mathrm{mg} / \mathrm{kg}$, ranging from 0.0047 to $0.0778 \mathrm{mg} / \mathrm{kg}$. Cd concentrations in both brown and polished rice did not exceed the $0.4 \mathrm{mg} / \mathrm{kg}$ maximum allowable $\mathrm{Cd}$ concentration in rice set by FAO/WHO. ${ }^{12}$

The NHQ values for adults ( $\geq 20$ years old) were less than 1.0 in both brown and polished rice with low $\mathrm{Cd}$ contents. Thus, $\mathrm{Cd}$ concentrations in brown and polished rice from the 9 farms in Barangay Real, Calamba City are unlikely to cause non-cancer health effects such as tubular proteinuria, decreased glomerular filtration rates, and itaiitai disease in adults as a result of long-term consumption.

Based on the results, the following recommendations can be drawn to better assess the Cd concentration in the surrounding environment and rice, and the non-cancer health risk:

1. Irrigation water and soil samples from the farms should be analyzed for $\mathrm{Cd}$. This is to better explain the source of $\mathrm{Cd}$ stored in the rice grains.

2. Another study should cover both dry and wet season to observe the effect of seasons on the $\mathrm{Cd}$ concentrations in rice, soil, and water.

3. For a site-specific risk characterization of exposure to $\mathrm{Cd}$ in rice, the following exposure data of the adult residents of Barangay Real, Calamba City should be collected: average daily consumption of rice; frequency of rice consumption in a year (number of days in a year); and the mean body weight of the adult residents. These data should be used in the calculation of the non-cancer hazard quotient.

4. This study is limited to only one source of Cd exposure, which is rice. Household surveys can be done to identify other possible sources or route of exposure to $\mathrm{Cd}$ by the residents such as other food sources (vegetables, shellfish, crustaceans, drinking water), cigarette smoke, and occupational exposure. 


\section{Acknowledgments}

We would like to extend our sincere gratitude to the City Agricultural Services Division and City Environmental and Natural Resources Office of Calamba and the farmers of Barangay Real for their assistance and cooperation. This study would not have been possible without the financial support from the Department of Science and TechnologyScience Education Institute (DOST-SEI) and Department of Environmental and Occupational Health (DEOH), College of Public Health, UP Manila.

\section{References}

1. Ji W, Chen Z, Li D, Ni W. Identifying the criteria of cadmium pollution in paddy soils based on a field survey. Energy Procedia. 2012; 16(A):2731

2. Kibria MG, Osman KT, Ahmed MJ. Cadmium and lead uptake by rice (Oryza sativa L.) grown in three different textured soils. Soil Environ. 2006; 25(2):70-7.

3. International Programme on Chemical Safety (IPCS), Cadmium Environmental Aspects: Environmental Health Criteria, No.135 [Online]. 1992 [cited 2013 Aug]. Available from http://www.inchem.org/documents/ehc/ehc/ehc135.htm.

4. Dong J, Mao WH, Zhang GP, Wu FB, Cai Y. Root excretion and plant tolerance to cadmium toxicity-a review. Plant Soil Environ. 2007; 53(5):193-200.

5. Bernard A. Cadmium \& its adverse effects on human health. Indian J Med Res. 2008;128(4):557-64.

6. International Programme on Chemical Safety (IPCS). Environmental Health Criteria 234: Elemental speciation in human health risk assessment. Switzerland: World Health Organization; 2006. p.144.

7. Jarup L. Cadmium overload and toxicity. Nephrol Dial Transplant. 2002;17(Suppl 2): 35-9.

8. Suwazono Y, Kobayashi E, Okubo Y, Nogawa K, Kido T, Nakagawa H. Renal effects of cadmium exposure in cadmium nonpolluted areas in Japan. Environ Res. 2000; 84(1):44-55.

9. Satarug S, Garrett SH, Sens MA, Sens DA. Cadmium, environmental exposure, and health outcomes. Environ Health Perspect. 2010; 118(2):182-90.

10. Yang QW, Lan CY, Wang HB, Zhuang P, Shu WS. Cadmium in soil-rice system and health risk associated with the use of untreated mining wastewater for irrigation in Lechang, China. Agr Water Manage. 2006; 84:147-52.

11. Fu J, Zhou Q, Liu J, et al. High levels of heavy metals in rice (Oryza sativa L.) from a typical E-waste recycling area in southeast China and its potential risk to human health. Chemosphere. 2008; 71(7):1269-75.

12. Food and Agriculture Organization/World Health Organization (FAO/WHO), Joint FAO/WHO Food Standards Programme Codex Committee on Contaminants in Foods: Fifth Session [Online]. 2011 [cited 2013 Aug]. Available from ftp://ftp.fao.org/codex/meetings/CCCF/ cccf5/cf05_INF.pdf.

13. City Agricultural Services Division. Agricultural Profile. Calamba City, Philippines: City Agricultural Services Division; 2012.

14. Department of Environment and Natural Resources (DENR). Watershed Characterization and Vulnerability Assessment of the San Juan River Watershed. Calamba, Laguna: DENR-Region 4A-CALABARZON; 2012. pp. xii, 41,82 .

15. US Environmental Protection Agency (EPA), Risk Assessment Guidance for Superfund Volume I: Human Health Evaluation Manual Supplemental Guidance Standard Default Exposure Factors [Online]. 1991 [cited 2013 Sept]. Available from http://rais.ornl.gov/ documents/OSWERdirective9285.6-03.pdf.

16. Habito C. Win-win with brown rice. Philippine Daily Inquirer [Online]. 2012 July 17. [cited 2014 Feb]. Available from http://opinion.inquirer.net/32743/win-win-with-brown-rice.
17. Bureau of Agricultural Statistics (BAS). Volume I: Philippines - Survey of Food Demand for Agricultural Commodities 2008-2009. Quezon City, Philippines: Bureau of Agricultural Statistics, Department of Agriculture; 2009. p. 63.

18. Food and Nutrition Research Institute (FNRI), Anthropometric Survey Component. 6th National Nutrition Survey [Online]. 2003 [cited 2013 Aug]. Available from http://www.fnri.dost.gov.ph/files/fnri\%20files/ nns/factsandfigures2003/anthropometric.pdf.

19. US EPA, Cadmium (CASRN 7440-43-9) [Online]. 1994 [cited 2013 Sept]. Available from http://www.epa.gov/iris/subst/0141.htm.

20. US EPA, Risk Assessment Guidance for Superfund Volume I: Human Health Evaluation Manual (Part A) [Online]. 1989 [cited 2013 Sept]. Available from http://rais.ornl.gov/documents/HHEMA.pdf.

21. Appleton JD, Weeks JM, Calvez JP, Beinhoff C. Impacts of mercury contaminated mining waste on soil quality, crops, bivalves, and fish in the Naboc River area, Mindanao, Philippines. Sci Total Environ. 2006, 354(2-3):198-211.

22. Solidum J, Dykimching E, Agaceta C, Cayco A. Assessment and identification of heavy metals in different types of cooked rice available in the Philippine market [Online]. 2012 [cited 2013 Feb]. Available from http://www.ipcbee.com/vol37/007-ICEAE2012-A00018.pdf.

23. Klaassen C, editor. Casarett \& Doull's toxicology: The basic science of poisons, $6^{\text {th }}$ ed. New York: McGraw-Hill; 2008. p. 940.

24. Kippler M, Goessler W, Nermell B, et al. Factors influencing intestinal cadmium uptake in pregnant Bangladeshi women-a prospective cohort study. Environ Res. 2009; 109(7):914-21.

25. Satarug S, Baker JR, Urbenjapol S, et al. A global perspective on cadmium pollution and toxicity in non-occupationally exposed population. Toxicol Lett. 2003;137(1-2):65-83. 